\title{
The Roots of Rwandan Genocide
}

\author{
Charles David Smith
}

\section{Pre-Independence}

Genocide is a cruel word, one that would not exist in a sane world. Yet how else can we describe Rwanda, where at least half a million people have been slaughtered since April 1994. Tens of thousands more are dying of cholera, hunger, and dehydration in overcrowded camps just across the border in Zaire. Even in the relatively well-supplied camps on the Tanzanian frontier, killers and victims coexist in a tense environment.

Rwanda is part of the interlacustrine zone of East Central Africa, bordered by Lake Victoria in the northeast and Lake Tanganyika in the southwest. Unlike most of tropical Africa, this region is densely populated and has a history of feudal-type states. Four hundred years ago in Rwanda, as elsewhere, the Hinda or Hima pastoral peoples (the Tutsi) established hegemony over the agriculturist Bantu, called Hutu in Rwanda. Yet hegemony was not exclusively or even primarily a matter of conquest, but really a fusion based on symbiosis. Tutsi herders raised cattle on land that would not support crops (composted cattle manure doubles or triples the yield of plantain, the staple food: see Smith, 1985). In the precolonial feudal state of Gasabo, both groups benefited from their association as they had more food and therefore could organize better defence and enjoy greater security.

As Nkongoli (1994) points out, Hutu and Tutsi could both change status and aspire to be decision makers. Even if a Tutsi king controlled a central state, it was the chiefs and subchiefs who ruled at a regional level, and the village elders who made most of the day-today decisions. The Germans controlled this area until it was mandated to

Charles Smith, Ph.D, is with the Department of Sociology, Moi University, Eldoret, Kenya. the Belgians in 1917. The Belgian legislature passed the Mortehan Law in 1926, which directed the Kings to appoint only Tutsi as chiefs, and gave the Kings and chiefs greater powers, salaries, and tax collection rights, which they often abused. When a King opposed Belgian laws or policy he could be deposed; this is what happened in 1931 when the Belgians deposed King Musinga and replaced him with his son Mutara III (Kamukama 1993).

The Tutsi chiefs were doubly resented because they enjoyed special privileges and, simultaneously, they had to enforce unpopular policies such as taxes, forced labour, and punishment for violators. By 1953, the Belgians realized that the appointed Tutsi chiefs were extremely unpopular and demanded that chiefs be elected. By this time the Hutu were rightly mistrustful of the Belgian authorities, and they resented the powers invested in the Tutsi minority, which accounted for about 15 percent of the population.

Poverty also fuelled the unrest. As early as the 1920s, the smallholder coffee growers of Uganda and the Bukoba region of Tanzania, themselves relatively poor farmers, began to hire Rwandese migrant coffee pickers at starvation wages. These impoverished landless or nearly landless Hutu, who migrated during the coffee harvest, were fleeing almost perpetual famine.

By the mid-1950s, the Hutu began to organize popular movements, such as the Hutu Social Movement and the Association for the Social Promotion of the Masses, both established in 1957. By 1959, the Hutu-based opposition joined forces under the banner of the Parti du Mouvement de l'Emancipation Hutu, PARMEHUTU. Militant anti-colonial Tutsi, wary of Hutu nationalism, set up their own party, the Union Nationale Rwandaise, UNAR. UNAR and PARMEHUTU militants first clashed in November 1959, and the result of this first ethnic conflict was that thousands of Tutsi were killed and at least 20,000 went into exile. Rwanda subsequently abolished the monarchy in January 1961, held two sets of elections, and gained independence on July 1, 1962.

\section{Post-Independence}

By the early 1960s, two dangerous patterns emerged: raids into Rwanda, and foreign intervention to prop up the Rwandese government. Many Tutsi were forced to flee their homeland and those that remained were subject to periodic repression. With little or nothing to lose, the Tutsi refugees began to launch the first guerrilla attacks. They called themselves Innyenzi (cockroaches), because they raided at night and then fled back across the Zairean, Ugandan, or Tanzanian borders. Although some Tutsi attained success in neighbouring countries, especially Uganda and, to a lesser extent, Tanzania, they never truly attained security in those countries where, as a warrior refugee community, they were both feared and mistrusted by neighbours and by governments wary of violating the Organization of African Unity $(O A U)$ rules against interfering in another African country.

Over one million Rwandans, who began arriving in the 1960 s, are residents of Uganda; about one-half of them are registered refugees (KidduMakubuya, 1994). Most settled in the southwestern part of the country where they would blend in with the Ankle, a related interlacustrine pastoral people. The United Nations High Commissioner for Refugees (UNHCR) set up six camps in this region where people were free to "come and gowith remarkable social consequences" (Kiddu-Makubuya, 1994). In the 1960s, the Obote government passed the Control of Alien Refugees Act, which made the Rwandans a special class of resi- 
dent subject to arbitrary questioning or even detention. In the 1970s, under Idi Amin, the government set up five large-scale ranching schemes that degenerated into violent conflict with local resident "squatters." The government blamed the Rwandan refugees for causing the trouble. By far the worst incident was in the Mbarara district in 1982, when officials launched a hate campaign against the Rwandese. Young members of Obote's Uganda People's Congress (UPC) formed gangs and a paramilitary special force that killed and raped at will. At least 35,000 Rwandans fled their homes. Many young men joined Musoveni's National Resistance Army (NRA) that was then in the bush, fighting a guerrilla war against Obote. When the NRA took power in 1986, there were at least five thousand wellarmed, experienced, and well-trained fighters who formed the core of the RPF armed forces. When they left the Ugandan army en masse in 1990, they took weapons with them, and therefore had at least covert support from the government of Uganda.

The second dangerous precedent was European interference in the Rwandan conflict. This began in 1959, when Belgian authorities detained 919 Tutsi compared to 312 Hutu. As early as 1961, the Rwandese army, led by Belgian officers, barely managed to repulse an invasion force of Tutsi attackers that came within 20 kilometers of Kigali. Tutsi-dominated guerrillas invaded ten times between 1961 and 1966. To counter these attacks, and in revenge, the Hutu organized gangs that killed tens of thousands of Tutsi, including the leaders of UNAR and other organizations. Later, in 1979, a few young $R$ wandese refugees formed the Rwandese Alliance for National Unity which, in 1987, forged itself into the Rwandese Patriotic Front, RPF. The RPF tried for three years to negotiate the unconditional return of all Rwandan refugees and to accord all $R$ wandese equal rights. After President Habaryimana stated that Rwanda was already overpopulated and could not take in any more people, the RPF took up arms. The RPF persisted despite heavy losses and the deaths of key military leaders, such as General Fred Rwigyema and Majors Chris Bunyenyezi and Peter Baingana, all killed in October 1990. After a series of attacks and reprisals, the RPF was close to military victory in January 1993, and it was only because of intervention by French, Belgian, and Zairian troops that the Habyarimana government could stay in power. The cruel irony here is that the same colonial powers who supported and strengthened the Tutsi monarchy, through subsequent military interventions, kept a million Tutsi refugees in exile by preventing a military victory.

On July 19, 1994 the RPF swore in a new government of "national unity;" but unity will be difficult to attain with one-half million refugees (mostly Hutu) in Tanzania and as many as two million panic-stricken Hutu flooding into Zaire, where tens of thousands are dying of cholera and starvation (Weekly Review, Kenya, July 22, 1994). The new President, Pasteur Bizimungu, and the new Prime Minister, Faustin Twagiramungu, are both Hutu, but there are few moderate Hutu left alive. Can the new government prevent killings in retaliation for the half-million people slaughtered by former members of Habyarimana's armed forces and the dreaded civilian militia, the interahamwe? Obviously, many of these ruthless killers are now refugees or in hiding. We can only hope that another round of slaughter can be avoided.

Judging by the previous experiences of Rwandans in exile, there is no permanent refuge in neighbouring countries. Tanzania has been the most generous country to date, but even there the political climate may at times present difficulties. Mwanza on Lake Victoria is the closest large Tanzanian city, and the Rwandan community there numbers about five thousand, including about one thousand new arrivals; almost all are Tutsi and relatively well-to-do, since they were the only ones who could reach this safe haven during the present emergency.
The day former President Habyarimana's plane was shot down, the Mwanza Rwandan community staged a public celebration. Given Tanzanian President Mwinyi's key role in trying to broker a negotiated settlement to the long-standing conflict, this public display was a misguided response. President Mwinyi was in Mwanza on official business and, when he learned of the celebration, he became upset because of the Arusha accord and Tanzania's role in trying to mediate the peace process. Mwinyi then ordered a roundup of the community leaders by the police. According to my sources (Street Kids International), they were later all released, but the community is keeping a very low profile and the newer arrivals are underground.

These Tutsi may have been in Tanzania for years; many young people have grown up in Mwanza, and some born in Tanzania are more Tanzanian than Rwandan. Will these youthful Tanzanian and Ugandan children of exiles want to repatriate? This will depend on their level of ethnic identity and on future developments in the war-torn nation. Rwanda will need the skills and determination of its exiles to attain peace and prosperity. is

\section{References}

Adelman, Howard and John Sorenson, (eds.) 1994. African Refugees: Development Aid and Repatriation. Boulder, CO: Westview Press, and North York: York Lanes Press.

Ayok-Chol, Anthony, and Maurice Mbago. 1990. "Refugee Settlementsin Tanzania: A CaseStudy of the Burundi Refugees." A paper presented at the International Seminar on Refugees in Africa, Arusha, Tanzania, July 30-August 3.

Bakwesegha, C.J. 1994. "Forced Migration in Africa and the OAU Convention." In Adelman and Sorenson, op. cit.

Bond, Virginia. 1988. "Identity Crisis: Banyarwanda RefugeesinUganda." M.A.dissertation, University of Edinburgh.

Botte, R. 1974. "Processus de Formation d'une classe sociale dansune societe Africains precapitaliste." Cahiers d'Études Africaines Vol. 14, No. 4: pp.60526.

Chilver, E.M. 1959. "Feudalism in the Interlacustrine Kingdoms." In Richards, A. I. (ed.), East African Chiefs. London.

D'Hertefelt, M.A.A. and Trouwborst, J.H. 1962. Les Anciens Royaumes de Zone Interlacustrine. Meridionale, Tervuren.

Continued on page 25 